\title{
Impediments and Inducements to Youth Entrepreneurship Development in Sylhet Region of Bangladesh- An Exploratory Study
}

\author{
Md. Shamimul Islam \\ Senior Lecturer, Department of Business Administration, Leading University, Sylhet, Bangladesh.
}

\begin{abstract}
The purpose of this paper is to explore and identify the key impediments and constraints that obstruct young people from starting and running a new venture and at the same time, inducements and stimuli that trigger youths to entrepreneurial activities. Data were collected from 80 young entrepreneurs of Sylhet, Bangladesh through a questionnaire gleaned from the literature review following a convenience and purposive sampling technique. Findings revealed, insufficient personal savings, high interest rate, and negative attitude of financial institutions to young entrepreneurs due to high default rate are the major impediments to obtaining start-up fund, being their own boss and earning more money are the prime inducements to engage in business. Parents and teachers influenced most to start business while financial risk reported as the most critical demotivator. Managing fund and fierce competition are main problems in running the business successfully. Lack of vocational education and training and inappropriate and inadequate curriculum and study programs are the key educational constraints, unsupportive tax regulations, complex business registration procedure are the leading administrative and regulatory barriers, dearth of information on available business support services and lack of training and business counseling are the major impediments of business support services. The implications of the study bear far-reaching ramifications to the concerned stakeholders for facilitating and encouraging youth entrepreneurship development by addressing the start-up constraints and problems.

Keywords: Enterprise start-up impediments, inducements, Entrepreneurship development, Youth entrepreneurship.
\end{abstract}

\section{Introduction}

Generating employment opportunities for young people is undeniably a prime agenda for Bangladesh since its youths constitute one third of the total population who if provided with proper supportive atmosphere to facilitate their entrepreneurial initiatives can drive economic development of the country. Youths are the vital workforce endowment who can accentuate the economic mounting through their creativities and qualities.

But reality of youth employment status is very frustrating, global youth unemployment level has soared tremendously since the 2008 economic crisis and it is estimated 73.4 million nearly 12.6 percent of the total youth population, representing an increase of 3.5 million between 2007 and 2013 and it is projected to rise to 12.8 percent of the total youth population in 2018 (ILO, 2013) ${ }^{[1]}$ and in Bangladesh nearly 2 million people entering into the labor market every year out of which 1 million remain unemployed (BBS, 2014) ${ }^{[2]}$. Growth in employment opportunities fall much behind the growth in population. Keeping this fact in mind, present government of Bangladesh has given special emphasis on new enterprise creation by enhancing access to formal financial scheme for SMEs of young people so that the contributions of entrepreneurial activities of these promising youths can turn Bangladesh a middle income country by the year 2021 as declared by the present government in its vision.

Bolstering youth entrepreneurship generates many positive effects on the country's economy through enhancing national revenue and consumer demand. According to ILO (2004), reducing youth unemployment could contribute to push the GDP up, societies may get direct economic benefits, crime and aggression as well as vulnerability and exclusion might be reduced ${ }^{[3]}$. Moreover decent work can change the status of young people from social dependence to self reliant and strengthening them to overcome poverty. It also offers youths a sense of belongingness and opportunities to realize their dreams and visions. Hence it is imperative to formulate consistent programs and policies that will boost youth employment and thus brings benefits to all in the long run (ILO, 2005) ${ }^{[4]}$.

Although there has been some research on the same issue but still there exist a general lack of in-depth research and concrete data on specific barriers and motivations that have bearings on youth entrepreneurship development in the context of developing country like Bangladesh. So this study is an effort to address this gap by providing a clearer and more comprehensive picture of youth entrepreneurship in general and of exploring a range of key impediments and hurdles that hinder young people of Bangladesh to successfully start and run businesses and at the same time identifying inducements and incentives that may trigger to enterprise start-ups 
by youths in particular. It is expected that findings of this study will stimulate policy debate among the practitioners and policy makers on the factors that foster or impede youth entrepreneurship and SME development. Moreover this paper adds to the existing literature of youth entrepreneurship by providing an update.

\section{Objectives of the Study}

The aim of the study is to explore and investigate the key impediments and constraints that obstruct young people from starting and running a new venture and at the same time, inducements and stimuli that trigger youths to entrepreneurial activities. In this connection, special emphasis has been given on the critical start-up issues like managing start-up finance, socio-cultural attitudes, access to business support services, administrative and regulatory structure and role of entrepreneurial education.

\section{Methodology of the Study}

To serve the purpose of the study a descriptive research approach has been adopted by extensively going through relevant literature on youth entrepreneurship and by interviewing young entrepreneurs to integrate their opinions into the study. To obtain young entrepreneurs' viewpoints and perceptions about the specific impediments and incentives influencing them on starting and running their businesses a questionnaire was developed from Schoof $(2006)^{[5]}$ with necessary modifications to adapt with the study purpose which is a SEED working paper of ILO on youth entrepreneurship. The sample of the study is 80 young entrepreneurs who were selected purposefully and conveniently from Sylhet a growing city of Bangladesh. In selecting the sample, a list of 100 young entrepreneurs from the study area was made out of which 90 young entrepreneurs were contacted through a team of 5 members to fill the questionnaire and finally 80 usable completed questionnaires was received with a response rate of $88.89 \%$. Before that a test re-test reliability assessment of the data collection instrument was conducted by distributing a set of questionnaire to ten young entrepreneurs of the study area and after few weeks later a set of identical questionnaires were distributed to the same study subjects and the responses for those two occasions were assessed for consistency and got seven of them correlated.

\subsection{Entrepreneurship and Youth}

\section{Literature Review}

Entrepreneurship is considered as a vehicle of creating new jobs and economic dynamism in developing countries. Therefore, without a generally agreed upon definition of "entrepreneurship" and " youth entrepreneurship" which is not observed in the existing literature, the issues relating to youth entrepreneurship can't be properly debated and hence the policy issues can't be precisely crafted. H. H. Stevenson and J. C. Jarillo, two highly regarded academics, define entrepreneurship as the process by which individuals pursue opportunities without regard to resources they currently control [6]. Francis Chigunta defines youth entrepreneurship as the practical application of enterprising qualities, such as initiative, innovation, creativity and risk-taking into the work environment (either in self-employment or employment in small start-up firms), using the appropriate skills necessary for success in that environment and culture ${ }^{[7]}$.

Countries vary considerably in their definition of youth and childhood. The UN considers individuals as youths who fall in the age group of 15-24 years (ILO, 2006) ${ }^{[8]}$. In India for example, youth is from 15 to 34 years of age, while in Pakistan and Srilanka it is 18 to 30 and 15 to 29 years of age respectively, in Bangladesh however, youths are those individuals who fall in the age cohort of 18 to 35 years.

\subsection{Impediments and Inducements to Youth Entrepreneurship 4.2.1 Socio-Cultural Impediments}

Cultural and societal attitude influence entrepreneurial activities and enterprise culture as the same way they shape an individual's approach to life. Thus cultural variations among the nations are increasingly considered as a key pointer for economic and entrepreneurial development. According to Gibb (1988), an enterprise culture is a set of attitudes, values, and beliefs shared within a community that leads to both "enterprising" behavior and aspiration to self-employment ${ }^{[9]}$. OECD asserted that a socio-cultural setting in which entrepreneurs are respected and valued and business failure is treated as a useful learning experience rather than a source of stigma, is more likely to be encouraging to entrepreneurship ${ }^{[10]}$. Culture influences the values and values again have influence on entrepreneurial behavior, decision to become an entrepreneur, needs and motives for achievement, pursuit of individual and social goals, orientation toward risk taking, proactiveness and self-efficacy of individuals (Harding, Cowling, \& Ream, 2003) ${ }^{[11]}$. To change young people's outlook toward entrepreneurship and business, parents, friends and relatives can play a vital role.

Image, reputation and credibility of entrepreneurs in the society also affect the choice of young people to become an entrepreneur. 


\subsubsection{Entrepreneurship Education Aspects}

Entrepreneurship education exerts a significant influence on young people to enhance entrepreneurial skills, competencies and behavior that are very imperative to be more agile and aware to assess entrepreneurship as a promising career option. Enterprise education has found to have significant impact on risk taking, starting new ventures and self employment generation (Charney and Libecap, 2000) ${ }^{[12]}$. Current findings of various studies show that entrepreneurship education encourages students to start their own business and has positive impact on student's self assessment and their attitude towards entrepreneurship as well as general occupational aspirations and achievement (Awongbenleand Luamadi, 2010; Fatoki and Chigonda, 2011; Owusu-Ansah and Poku, 2012) ${ }^{[13],[14],[15]}$.

\subsubsection{Impediments in-terms of Accessing on Start-up Finance}

One of the major impediments to enterprise start-up by young people is dearth of adequate start-up fund. According to Moog (2005) about 78 percent of the respondents aged between 15-24 years old compared to 73 percent of other age cohort agreed that lack of available financial support is more a severe barrier than administrative burdens or an unfavorable economic climate ${ }^{[16]}$. Young people in fact face age discrimination because banks and other financial institutions don't find them safe to invest due to shortage of resources, lack of dependable credit history and security. High interest rate and fess, complex documentation procedures, unfavorable firm and industry characteristics, legal status of the enterprise, lack of seed funding and knowledge of financing possibilities also impede young entrepreneurs to manage start-up finance.

\subsubsection{Administrative and Regulatory Impediments}

Bureaucratic and legal complexities are also found to be very dominant impediments towards starting new enterprise by youths in developing countries (World Bank, 2005) ${ }^{[17]}$. Entrepreneurs face numerous administrative burdens like complex business registration, tax administration, obtaining investment approval and business license, copying with copyright and patent regulations, access to work spaces and long-term leases, building construction permits, customs clearances, utility hook-ups etc.

\subsubsection{Business Assistance and Support}

Key support services including mentoring, suitable network supports, business clubs and incubators can help youths to enterprise strat-ups. There have been many other key deficiencies indentified in the literature (Derby, 2004) on the same area like lack of business connections, suppliers, suitable partners and networks, lack of knowledge of available business support services, lack of youth specific business training and advices, insufficient ICT infrastructure, absence of forums and meeting places etc. ${ }^{[18]}$.

\subsubsection{Inducements for Youths to Engage in Enterprise Start-ups}

There are many factors that trigger young people to start new businesses which are related to their life style, personal attitudes, preferences, interests, strengths and competencies. Limited employment opportunities, needed to support family income and poverty are the dominant reasons for youths to engage in entrepreneurial activities especially in low-income and developing countries (Chigunta, 2002) ${ }^{[19]}$. According to (Prabhu,1999, Henton, Melville\& Walesh,1997) need to be true to one's beliefs and values, to be socially responsible, to contribute in the health of local economy are the personal motivation and causes for youths to engage in business start-ups ${ }^{[20],[21]}$. Most cited reasons for starting businesses by young people in developing countries are to be one's own boss, to enjoy more freedom and flexibility, to take challenge, to earn more money, to gain recognition and reputation in the society, to enjoy a better quality of life and continue the family traditions.

\subsection{Obstacles during the business start-ups}

\section{Analysis of Data}

Information was sought on the various obstacles that young entrepreneurs encountered during their business start-ups and thereby they were asked to rank from a list of factors that created the most difficult barrier during the initial stages of starting their business.

Table 1: Start-up impediments/ obstacles

\begin{tabular}{|l|l|l|}
\hline Rank & Start-up impediments & Percentage \\
\hline 1 & Access to start-up finance & $42.5 \%$ \\
\hline 2 & Govt. regulations & $28.75 \%$ \\
\hline 3 & Lack of business support services and physical infrastructure & $25 \%$ \\
\hline 4 & Socio-cultural attitude toward entrepreneurship & $21.25 \%$ \\
\hline 5 & Lack of education, skills and training & $12.5 \%$ \\
\hline
\end{tabular}


Table 1. Shows the results that indicate access to start-up finance or credit was ranked as the number one $(42.5 \%)$ impediment to start their business. Govt. regulations like excessive administrative and bureaucratic burdens that make business start-up process time consuming, cumbersome, complex was ranked second most difficult barrier (28.75\%). Lack of business support services and physical infrastructure was reported as the third most important problem (25\%) for starting a business. Negative socio-cultural attitude toward entrepreneurship and lack of adequate education and training were also found important impediments for youths to start their business.

\subsection{Factors induced youths to be entrepreneurs}

Table 2: Major inducements/motivators to be entrepreneur

\begin{tabular}{|l|l|l|}
\hline Sl. & Inducements/Motivators & Percentage \\
\hline 1 & To be my own boss & $58.75 \%$ \\
\hline 2 & To earn more money/ Become rich & $38.75 \%$ \\
\hline 3 & To realize my ideas/ vision & $36.25 \%$ \\
\hline 4 & To do something new & $35 \%$ \\
\hline 5 & Opportunities in the sector & $33.75 \%$ \\
\hline 6 & To be respected in the society & $32.05 \%$ \\
\hline 7 & To connect my business with my passion/hobby & $26.25 \%$ \\
\hline 8 & Success stories of others & $22.5 \%$ \\
\hline 9 & To seek the challenge & $20.75 \%$ \\
\hline 10 & Region specific advantage & $7.5 \%$ \\
\hline
\end{tabular}

"To enjoy financial and personal freedom and to live smoothly by earning more money I started my business" (Md. Sumon Mia, a young entrepreneur from Sylhet, Bangladesh). Table 2 outlines the results of factors influencing young people to be an entrepreneur. It is seen from the table that the main factors influencing them are to be their own boss $(58.75 \%)$, to earn more money $(38.75 \%)$, to realize their ideas or vision $(36.25 \%)$. Some other motivational factors are to do something new, opportunities in the sector and to be respected in the society etc.

\subsection{Influencers to start a business}

Table 3: Influencers to start a business

\begin{tabular}{|c|c|c|c|}
\hline Factors & Degree of influence & Frequency & Percentage \\
\hline \multirow[t]{5}{*}{ Parents and family } & Most influencer & 37 & $46.25 \%$ \\
\hline & Positively influencer & 35 & $43.75 \%$ \\
\hline & Negatively influencer & 4 & $5 \%$ \\
\hline & No influencer & 3 & $3.75 \%$ \\
\hline & Don't know & 1 & $1.25 \%$ \\
\hline \multirow[t]{5}{*}{ Career advisor } & Most influencer & 28 & $35 \%$ \\
\hline & Positively influencer & 34 & $42.5 \%$ \\
\hline & Negatively influencer & 3 & $3.75 \%$ \\
\hline & No influencer & 11 & $13.75 \%$ \\
\hline & Don't know & 4 & $5 \%$ \\
\hline \multirow[t]{5}{*}{ Teacher } & Most influencer & 19 & $23.75 \%$ \\
\hline & Positively influencer & 36 & $45 \%$ \\
\hline & Negatively influencer & 5 & $6.25 \%$ \\
\hline & No influencer & 15 & $18.75 \%$ \\
\hline & Don't know & 5 & $6.25 \%$ \\
\hline \multirow[t]{5}{*}{ Entrepreneurs } & Most influencer & 25 & $31.25 \%$ \\
\hline & Positively influencer & 34 & $42.5 \%$ \\
\hline & Negatively influencer & 2 & $2.5 \%$ \\
\hline & No influencer & 13 & $16.25 \%$ \\
\hline & Don't know & 6 & $7.5 \%$ \\
\hline \multirow[t]{5}{*}{ Media } & Most influencer & 9 & $11.25 \%$ \\
\hline & Positively influencer & 28 & $35 \%$ \\
\hline & Negatively influencer & 5 & $6.25 \%$ \\
\hline & No influencer & 30 & $37.5 \%$ \\
\hline & Don't know & 8 & $10 \%$ \\
\hline \multirow[t]{5}{*}{ Friends } & Most influencer & 33 & $41.25 \%$ \\
\hline & Positively influencer & 23 & $28.75 \%$ \\
\hline & Negatively influencer & 5 & $6.25 \%$ \\
\hline & No influencer & 14 & $17.5 \%$ \\
\hline & Don't know & 5 & $6.25 \%$ \\
\hline
\end{tabular}

Table 3 indicates the percentages of different influencers who encourage, discourage young entrepreneurs to start their business. The most influencers, according to the opinions of respondents are parents 
Impediments and Inducements to Youth Entrepreneurship Development in Sylhet Region of ..

and family (46.25\%), teachers, entrepreneurs and career advisors positively influenced them moreover, different media and friends also play an important role to encourage or discourage young people to engage in business activities. A respondent named Mamunur Rashid from Sylhet said "My parents and friends strongly supported me when I started my business by providing continuous suggestions and courage that boosted-up my confidence and passion for the business".

\subsection{Major impediments to obtaining start-up funding}

Table 4: Impediments to start-up funding

\begin{tabular}{|l|l|l|}
\hline Sl. & Impediments & Percentage \\
\hline 1 & Insufficient personal savings & $52.5 \%$ \\
\hline 2 & Negative attitude of financial institutions to young entrepreneurs due to high default risks & $45 \%$ \\
\hline 3 & High interest rates and fees & $40 \%$ \\
\hline 4 & Complex documentation procedures & $36.25 \%$ \\
\hline 5 & High collaterals/assets/guarantees requirements (In case of getting loan from banks ) & $23.75 \%$ \\
\hline 6 & Lack of knowledge on available options of financing scheme & $22 \%$ \\
\hline 7 & No legal status of enterprise (informal sector), etc & $21.25 \%$ \\
\hline 8 & Lack of seed funding or subsidies from GOs and NGOs & $18.75 \%$ \\
\hline 9 & Lack of financial literacy/ youth -friendly financial products & $17.50 \%$ \\
\hline 10 & Strict credit-scoring methodologies/regulations & $10 \%$ \\
\hline
\end{tabular}

Table 4 exhibits the major impediments that young entrepreneurs face in obtaining start-up funds such as: insufficient personal savings, negative attitude of financial institutions to young entrepreneurs, high interest rates and fees, complex documentation procedures, lack of sufficient collateral or guarantees to secure loans and lack of knowledge on available options of financing scheme. Md. Saroar Jamil a young entrepreneur opined that "Banks are very much averse to give loan to young entrepreneurs and they ask for high collaterals and interest rate yet documentation procedures are very complicated that frustrated me a lot."

\subsection{De-motivators or fears to engage in business}

Table 5: De-motivators /fears to engage in business

\begin{tabular}{|l|l|l|}
\hline Sl. & De-motivators & Mean \\
\hline 1 & Access to finance - Capital to invest & 3.95 \\
\hline 2 & Competition & 3.80 \\
\hline 3 & Financial risks & 3.55 \\
\hline 4 & Stigma associated with failing & 3.40 \\
\hline 5 & Gender & 3.15 \\
\hline 6 & Lack of skills (confidence in my skills \& experience) & 3.10 \\
\hline 7 & Workload & 3.05 \\
\hline 8 & Corruption & 3.05 \\
\hline 9 & Administrative hurdles & 2.80 \\
\hline 10 & Social (protection) risks or costs & 2.65 \\
\hline 11 & Market demand & 1.86 \\
\hline
\end{tabular}

It is noticed from Table 5 that the de-motivators or fears that refrain young people to engage in entrepreneurial activities. Access to finance, fierce competition, financial risk and stigma associated with failing are the key de-motivators that create fears among the young people to start new business. Marker demand, social risks, administrative hurdles, corruption are less cited de-motivators.

\subsection{Influence of education}

Table 6: Influence of education

\begin{tabular}{|l|l|l|}
\hline Sl. & Particular & Percentage \\
\hline 1 & Influenced my entrepreneurial career positively & $48.75 \%$ \\
\hline 2 & Strongly supported my entrepreneurial career & $36.25 \%$ \\
\hline 3 & Had a positive influence on my career & $21.25 \%$ \\
\hline 4 & Had a negative influence on my entrepreneurial career & $16.25 \%$ \\
\hline 5 & Impeded my entrepreneurial career & $2.51 \%$ \\
\hline
\end{tabular}

As of Table 6 that shows the influence of education on entrepreneurial initiatives. $48.75 \%$ respondents reported that education influenced their entrepreneurial career positively and another $36.25 \%$ respondents said education strongly supported their entrepreneurial career. Surprisingly $16.25 \%$ respondents opined education negatively influenced their entrepreneurial career and another $2.51 \%$ said that education impeded their entrepreneurial career. This might be due to their wrong perception regarding how education could contribute their career or they might have thought that if they could start their business earlier without going for study they could do better in their business. 


\subsection{Key impediments to business support services}

Table 7: Key impediments relating to business support services

\begin{tabular}{|l|l|l|}
\hline Sl. & Impediments & Percentage \\
\hline 1 & Lack of information on available business support services & $50 \%$ \\
\hline 2 & Lack of youth specific training and business counselling & $46.25 \%$ \\
\hline 3 & Lack of mentoring services & $27.5 \%$ \\
\hline 4 & Unavailable ICT technology and programs to youth & $25 \%$ \\
\hline 5 & Lack of agencies that facilitate skills acquisition by young peoples & $21.25 \%$ \\
\hline 6 & Lack of suppliers, suitable partners, networks and contract & $16.25 \%$ \\
\hline
\end{tabular}

As shown in Table 7, 50\% of young entrepreneurs reported that lack of information on available business support services is the most important constraint to start and survive with small business. $46.25 \%$ respondents said that there is a lack of customized training and business counseling focusing on technical aspects of starting-up a business. Some other impediments are lack of mentoring services, unavailable ICT technology and programs to youth etc. Respondents opined that if promotional efforts like research and business assistance, provisions for training, advice and counseling, working infrastructures, enterprise integration and linkages are made available then youth enterprise start-up will boost up in Bangladesh.

\subsection{Major educational constraints in setting-up business}

Table 8: Major educative impediments

\begin{tabular}{|l|l|l|}
\hline SI. & Impediments & Percentage \\
\hline 1 & Lake of vocational education and training & $41.25 \%$ \\
\hline 2 & Lack of well trained teacher & $37.50 \%$ \\
\hline 3 & Lack of supportive educational infrastructure & $33.75 \%$ \\
\hline 4 & $\begin{array}{l}\text { Education and training do not promote/encourage young people to engage in } \\
\text { business and to develop good business ideas. }\end{array}$ & $30 \%$ \\
\hline 5 & Education and training don't match market opportunities & $25 \%$ \\
\hline 6 & Inappropriate and inadequate curriculum and study program & $16.25 \%$ \\
\hline
\end{tabular}

The key shortcomings in the current education structure of Bangladesh are presented in Table 8. Some key educative constraints are lack of vocational education and training, lack of well trained teachers and lack of supportive educational infrastructure etc. A young entrepreneur named Farid Uddin from Sylhet said "our education system and study program are more likely to produce employees not employers or entrepreneurs." Teachers have limited experience on small businesses and are not well trained to teach entrepreneurial skills enhancement techniques. He suggested that our curriculum should focus more on youth specific enterprise starup initiatives, our teacher should be trained properly, more practical, experimental tools and resources should be made available.

\subsection{Major socio-cultural impediments during starting a business}

Table 9: Most important socio-cultural barriers

\begin{tabular}{|l|l|l|}
\hline Sl. & Barriers & Percentage \\
\hline 1 & Society view young people as unstable and unreliable & $45 \%$ \\
\hline 2 & Fear of being rejected & $41.25 \%$ \\
\hline 3 & The fear of failure & $36.25 \%$ \\
\hline 4 & Allowing youths to do business is supposed to be too risky by family & $25 \%$ \\
\hline 5 & Gender discrimination & $17.5 \%$ \\
\hline 6 & Society does not appreciate and promote entrepreneurship & $17.5 \%$ \\
\hline 7 & Low value assigned to entrepreneurial activities. & $17.5 \%$ \\
\hline
\end{tabular}

The main socio-cultural barriers, as shown in Table 9, are society view young people as unstable and unreliable. Another major socio-cultural barrier for young entrepreneur is the existence of fear of being rejected. "Our society values more on doing job for others rather than doing job for own business, I am a business graduate and I wished to start a business but my family didn't allow me to do it rather they emphasized on doing a private or public job, so after doing job for several years I started my own business and now I am doing well" said a young entrepreneur named Md. Jalal Uddin of Sylhet. 
Impediments and Inducements to Youth Entrepreneurship Development in Sylhet Region of ..

\subsection{Major problems while running the business}

Table 10: Problems of running business

\begin{tabular}{|l|l|l|}
\hline Sl. & Particulars & Percentage \\
\hline 1 & Competition & $51.25 \%$ \\
\hline 2 & Difficulty in managing fund & $40 \%$ \\
\hline 3 & Insufficient tactical skills for growth and transformation & $36.25 \%$ \\
\hline 4 & Difficulty in managing stress & $31.25 \%$ \\
\hline 5 & Problems in debt recovery & $26.25 \%$ \\
\hline 6 & Finding customers & $23.75 \%$ \\
\hline 7 & Corruption & $22.5 \%$ \\
\hline 8 & Lack of support from family or friends. & $12.25 \%$ \\
\hline 9 & $\begin{array}{l}\text { Not being taken seriously by colleagues or business } \\
\text { contacts }\end{array}$ & $1.25 \%$ \\
\hline
\end{tabular}

Table 10 outlines the problems faced by the young entrepreneurs while running their businesses. It is noticed from the table that $51.25 \%$ respondents reported fierce competition in the market as the most critical problem in running their businesses. It is also noticed that $40 \%$ respondents said managing funds from different sources was very difficult. Other problems they cited were insufficient tactical skills, difficulty in managing stress, problems in debt recovery and due to their age and life experience young entrepreneurs are not taken seriously by business contacts and others.

\subsection{Bureaucratic and regulatory barriers}

Table 11: Administrative and regulatory impediments

\begin{tabular}{|l|l|l|}
\hline Sl. & Impediments & WA \\
\hline 1 & Complex, costly and unreasonably lengthy business registration process & 3.80 \\
\hline 2 & Unsupportive tax regulations & 3.68 \\
\hline 3 & Poorly enforced or too strict property, patent and copyright regulations & 3.53 \\
\hline 4 & Unclear ownership rules and access to land & 3.35 \\
\hline 5 & Bankruptcy laws & 3.05 \\
\hline 6 & Subsidy policy & 2.50 \\
\hline
\end{tabular}

The main administrative hurdles, as shown in Table 11, are the complex, costly and unreasonably lengthy business registration process and unsupportive tax burdens which may through cold water in starting a business. Poorly enforced property, patent and copyright regulations may largely discourage young people to enterprise start-ups. Reducing and simplifying the regulatory and administrative barriers will stimulate and encourage youths to more entrepreneurial activities.

\section{Conclusion and Recommendations}

The study highlights constraints that hinder young people from starting and running a business and at the same time incentives that makes starting a business viable alternative for young people in Bangladesh. It is found that during the start-up and early stages of their businesses, the young entrepreneurs are confronted by a myriad of problems which negatively affect youth entrepreneurship in Bangladesh. The most critical of these are related to lack of access to finance, lack of business support assistance and negative social and cultural attitude to entrepreneurship. In addition, the young entrepreneurs encounter problems relating to administrative and regulatory framework and getting enough customers. Some important motivators to be an entrepreneur are being boss of their own, earning more money and realizing their own ideas. Parent and family, career advisors, teachers or lectures and successful entrepreneurs are the key influencers for young people to engage in entrepreneurial activities. Lack of personal savings, negative attitude of financial institutions to young entrepreneurs, high interest rates and complex documentation procedures are the key constraints to start-p funding. The most important de-motivators that create fears among young people to start new business ventures are access to finance, competition, financial risk and stigma associated with failing. Lack of information on available business support service, lack of training and business counseling and lack of mentoring services are the main barriers related to business support services. Lack of vocational education and lack of well trained teacher and lack of supportive educational infrastructure are the major educational constraints in setting-up a business. The respondent opined that the major problems they faced while running a business are competition, difficulties in managing fund and insufficient tactical skills for growth and transformation.

A good number of recommendations have been offered to strengthen the youth entrepreneurship development initiatives as follows:

- Awareness of business opportunities and support services offered by various agencies should be targeted towards youth entrepreneurs.

- Youth entrepreneurship support structures need to create an awareness campaign about their existence.

- Government should take actions to reduce costs associated with business registration for youth, as most of them tend to lack requisite finance. 
- Separate banks may be established for youth entrepreneurs and for the other banks; an obligation may be imposed to maintain a minimum quota for the youth entrepreneurs.

- A comprehensive credit policy should be initiated under the direct supervision of the central bank in order to create access of youth to finance. The policy should contain a provision of collateral free loan, credit without interest or low rate of interest, loan for long time duration.

- Proper coordination, necessary fund and trained staff should be provided by the GOs and NGOs to improve service delivery mechanisms.

- Counseling on project ideas, techniques for selecting suitable projects, preparation of business plan, management, sustaining support etc. should be provided by the concern entities to create and maintain youth entrepreneurship friendly environment.

- Increase research program on youth entrepreneurship development and provide financial support by the government to the institutions that are currently involved in research activities on youth entrepreneurship development.

- Introduce lesson on entrepreneurship development in educational curriculum. According to White and Kenyon (2001), interventions in entrepreneurship education can be resource intensive and are in general long-term investments ${ }^{[22]}$.

- Harmony and coordination among the policy institutions need to be ensured.

- Strategies to maintain enthusiasm of youth in entrepreneurial activities need to emerge and be correctly implemented. This could be achieved through the creation of favorable business environment, where the business support services are accessible to young people. Government's youth entrepreneurship support structures should partner with local youth entrepreneurship organizations in staging workshops, conferences and symposia aimed at nurturing young entrepreneurs.

\section{Limitation of the Study}

The study has been conducted on young entrepreneurs doing business in Sylhet a north-eastern city of Bangladesh. Therefore, it might not be appropriate to make generalizations of the findings.

\section{References}

[1]. (ILO, 2013) - International Labor Organization (2013). Global employment trends for youth: A generation at risk, Geneva.

[2]. (BBS, 2014) Statistical Year Book of Bangladesh, Statistic Division, Ministry of Planning, Bangladesh Govt. of People Republic, Dhaka. (www.bbs.gov.bd/dataindex/stat_bangladesh.pdf)

[3]. ILO (2004): "Starting rights: Decent work for young people". Background paper, Tripartite Meeting on Youth Employment: The Way Forward, Geneva, 13-14 October 2004.

[4]. ILO (2005): "Youth Pathways to decent work". Report VI promoting youth employment - Tackling the challenge, ILC, 93 Session.

[5]. Schoof. U. (2006), Stimulating Youth Entrepreneurship: Barriers and incentives to enterprise start-ups by young people. SEED Working Paper No. 76, ILO, Geneva

[6]. Barringer, B. R.; Ireland, R. D.(2012). Entrepreneurship ( $3^{\text {rd }}$ ed.) (Chapter 1), p.30

[7]. Riahi, S.: "Youth Entrepreneurship: Ottawa's Portfolio in Talent Development".

[8]. ILO (2006). Stimulating Youth Entrepreneurship: Barriers and Incentives to Enterprise Start Ups by Young People. SEED Working Paper No. 76.

[9]. Gibb, A. A. (1998). "Stimulating New Business Development" What Else Besides EDP. In: Stimulating Entrepreneurship and Business Development (chapter 3), ILO, Geneva.

[10]. OECD, (1988). Fostering Entrepreneurship. Paris.

[11]. Harding, R.; Cowling, M.; Ream, M. (2003): “Achieving the Vision”, Female Entrepreneurship, published by the British Chambers of Commerce, London.

[12]. Chamey, A.; Libecap, G. D. (2000): The Impact of Entrepreneurship Education: An Evaluation of the Berger Entrepreneurship Program at the University of Arizona, 1985-1999, Report to the Kauffman Center for Entrepreneurial Leadership, Kansas City, Missouri.

[13]. Awongbenle, A.C. \& Lwuamadi K.C. (2010) Youth Unemployment: Entrepreneurship Development Program as an Intervention Mechanism. African Journal of Business Management. 14(6). 831-835

[14]. Fatoki, O. \& Chidoga, L (2011) An investigation into the obstacles to youth entrepreneurship in South Africa. International Business Research.4(2)

[15]. Owusu-Ansah \& Poku (2012) Entrepreneurship Education, A panacea to Graduate Unemployment in Ghana. International Journal of Humanities and Social Science. 2(15)

[16]. Moog, P.(2005): Good practice in der entrepreneurship-Ausbildung-Versuch eines international Vergleichs, Syudie erstellt fur den Forderkreis fur Grundugsforschung (FGF), Bonn.

[17]. World Bank (2005).Doing Business in 2006-Creating Jobs. Annual Report, Washington D.C

[18]. Darby (2004) The Young Entrepreneur-Revisited, RSA. Onian Fellowship 2001, London.

[19]. Chigunta, F. (2002) Youth Entrepreneurship: Meeting the Key Policy Challenges. Wolf Son College, Oxford University, England.

[20]. Prabhu, G.N. (1999) Social Entrepreneurship Leadership, Career Development International, 4(3), pp.140-45

[21]. Henton, D. Melville, J., Walesh, K.(1997) The age of civic entrepreneur: restoring civil society and building economic community, National Civic Review, 86(2), pp149-157.

[22]. White, S.; Kenyon, P. (2001): "Enterprise-Based Youth Employment Policies, Strategies and Programs". Initiatives for the development of enterprise action and strategies, Working Paper, InFocus Program on Skills, Knowledge and Employability, ILO, Geneva. 